\title{
Research on the Design and Practice of Climbing Route of Unclimbed Mountain-A Case Study of Ruoni Mountain II
}

\author{
Li Lun \\ Sports Department \\ China University of Geosciences (Wuhan) \\ Wuhan, Hubei, China 430074
}

\begin{abstract}
Climbing route is the core achievement of climbing unclimbed mountain, for a determined climbing route can provide safety guarantee for later climbers and also provide reference for them to create new climbing routes. Therefore, each climbing success of unclimbed mountain is a process in which climbers risk their life to explore and design climbing route. During mountain climbing, correct design and choice of climbing route is directly related to the life safety and climbing success or failure. This paper takes the example of Ruoni Mountain II, conducts an exploratory research on the design and choice of the climbing mountain of unclimbed mountain, and introduces the successful practice experience for reference of both domestic and foreign climbers.
\end{abstract}

\section{Keywords-unclimbed mountain; route design; Ruoni Mountain II}

\section{INTRODUCTION}

George-Sarton, the world's most famous science historian believes that science history is the most important part of human civilization, because it is the only history that can give a precise reflection of human progress [1]. Moreover, the several thousand years-long human civilizations are developed by exploring the unknown. The development from sharpening stone into axe and getting fire by boring wood to interstellar exploration and clean energy, and from unknown to known all benefits from the assiduous exploration of mankind.

In 1786, H.Dasonsul, a scientist from Geneva painstakingly climbed the Mont Blanc with an altitude of $4,807 \mathrm{~m}$ only to explore alpine plants, but unexpectedly give rise to the modern mountaineering and make it spread from the Alps to the whole world [2]. The earth's orogeny not only turns high mountain into a rich biological treasure, and the cultural deposits such as the bioglyph, geological structural change, natural environmental change and other fields also induces the mankind to climb high mountains and unveil their mystery. This also leads to the rapid development of mountaineering especially the climbing of unclimbed mountain.

Located at the southeast of Tibet, Ruoni Mountain II belongs to the Kangri Garpo mountain range. In 2003, a Japanese mountaineering team from Kobe University climbed the mountain for the first time, but failed to reach the summit; in 2005, a Swiss mountaineering team tried three climbing routes altogether but also failed to reach the summit. During October 18th to November 11th in 2009 , China University of Geosciences (Wuhan) and Japanese Kobe University made a joint mountaineering team for the third trial and finally it succeeded. On October 5th and 7th of that year, four people climbed up to the top in two groups. In order to provide climbing route as reference for later climbing teams and satisfy the actual need of scientifically setting the climbing route, during the time, the climbing team conducts a route survey, and obtained impressive results. For example, according to GPS measurement, the actual altitude of the mountain is 6,805 meters instead of the previously told 6,800 meters.

This paper reports the research results on the design and practice of the climbing route for this mountaineering, which can provide beneficial reference for later climbers, the scientific investigation and research of China's mountaineering movement, and protection of high mountain resources.

\section{RESEARCH METHODOLOGY}

Documentation method - before this event begins, literature documents about mountain climbing route design, alpine observation, and environmental climate etc around Ruoni Mountain were investigated to lay a theoretical basis for this climbing route.

Expert interview- mountaineering experts and athletes were interviewed to understand the geomorphic feature of Ruoni Mountain II, and obtain experience and suggestions on climbing route design of unclimbed mountains.

Field research- in October 2008, the joint mountaineering team from China University of Geosciences (Wuhan) and Japanese Kobe University made a field investigation on the climbing environment of Ruoni Mountain II. During the survey, GPS (eTrex Vista HCx) was applied for precise route location. The characteristics of the climbing route were observed and detailed records were made. By contrasting the accumulated snow on different routes of Ruoni Mountain II, Ruoni Mountain II, its surrounding environment and climate change were initially studied to provide rich empirical information for the determination of climbing route.

Investigation method- before climbing, review investigation was conducted on the local mountaineering management department and the surrounding residents of Ruoni Mountain II, so as to understand the natural 
environment, structural characteristics and notes for climbing.

Measurement method - elevation, measuring longitude, latitude and altitude by GPS locating; contrasting accumulated snow of different climbing routes of Ruoni Mountain II through field investigation.

Observation method- observation and a detailed record of the features, climbing environment and climate changes of the climbing route.

\section{RESULTS AND ANALYSIS}

\section{A. Profile of Ruoni Mountain II}

The whole Kangri Garpo mountain range is $280 \mathrm{~km}$ long, and there are 34 independent summits with altitude over $6 \mathrm{~km}$. Ruoni Mountain II is located in the east of the mountain group, which belongs to the unclimbed mountain. See table 1 for the basic profile of the summit.

TABLE I.

BASIC PROFILE OF RUONI MOUNTAIN II

\begin{tabular}{|c|c|}
\hline Indicator & Basic information \\
\hline $\begin{array}{l}\text { Geographic } \\
\text { position }\end{array}$ & $\begin{array}{l}\text { Kangri Garpo mountain range located in the } \\
\text { southeast of Tibet }\end{array}$ \\
\hline Altitude & $6,805 \mathrm{~m}$ \\
\hline Climate & $\begin{array}{l}\text { The climate in the Ruoni Mountain region is } \\
\text { complicated and diversified, similar to that of } \\
\text { Mount Everest. The winter half year is try and } \\
\text { windy, which is the try and wind season. The } \\
\text { summer half year is rainy season, which takes on } \\
\text { the plateau continental climate. }\end{array}$ \\
\hline Environment & $\begin{array}{l}\text { There are } 34 \text { independent summits with altitude } \\
\text { over } 6 \mathrm{~km} \text { in the entire Ruoni mountain region, } \\
\text { among which the highest summit is Ruoni } \\
\text { Mountain II and it is an unclimbed mountain. }\end{array}$ \\
\hline Approach route & $\begin{array}{l}\text { Going towards the east along Sichuan-Tibet } \\
\text { highway, through Bayi and Bomi, reaching } \\
\text { Ranwu Lake; then going south for } 30 \mathrm{~km} \text { along } \\
\text { rough road, reaching Lagu Village, and finally } \\
\text { arriving at the mountaineering camp at the end of } \\
\text { Lagu Glacier. The altitude here is } 4,300 \mathrm{~m} \text {; the } \\
\text { terrain is relatively wide and wind proofing, and } \\
\text { sufficient with water. }\end{array}$ \\
\hline $\begin{array}{c}\text { Climbing } \\
\text { opportunity }\end{array}$ & $\begin{array}{l}\text { During October to November, it is a time which } \\
\text { wind season and rainy season transits towards } \\
\text { each other. Generally there are three to four times } \\
\text { of good weather lasting for two to five days. Such } \\
\text { periods are the best time for mountaineering. The } \\
\text { cycle for nice weather usually lasts for a long } \\
\text { time, which is generally about two weeks. }\end{array}$ \\
\hline
\end{tabular}

\section{B. Climbing Route Design of Ruoni Mountain II}

\section{1) Principle of climbing route design}

A mature climbing route of a mountain is concluded by effortful exploration of numerous climbers, and it is necessary to choose the most appropriate line according to the entire summit or even the whole mountain range. The overall distance of the route should not be too long, and the following factors need to be considered: local climate, orographic factor, material conditions, and the condition of team members, etc.

\section{a) Regional and climatic factors}

Climate is an important factor that influences mountaineering. Mountain climbing can be successful only when it is arranged according to the climatic characteristics of the mountain region, i.e. the so called "climbing season". Kangri Garpo mountain range has the same latitude with Meri Snow Mountain in Yunnan, and it is highly influenced by the climate of local area, and air flow can trace the valley up, which is influenced by the monsoon. The climate is precarious, and weather may change in a moment. Generally, each year between the early June to middle September is the rainy season, and downpour brought by strong southeast monsoon causes frequent ice slide and avalanche, resulting in cloudy and misty weather with ice and snow. During the mid-December to the mid-February of next year, due to control of strong northwest cold current, the temperature may reach $-40^{\circ} \mathrm{C}$, with average temperature between $-30^{\circ} \mathrm{C}$ to $-50^{\circ} \mathrm{C}$. The maximum wind speed may reach $90 \mathrm{~m} / \mathrm{s}$. Therefore, there are some ice glaciers in the Kangri Garpo mountain range, with bright and dark ice cracks, frequent avalanche, and complicated and diversified climate.

\section{b) Safety}

Due to geographic location and climate features, there are multiple dangerous road sections in the Kangri Garpo mountain range. Therefore, the safety of climbers must be fully considered. During the climbing, ice cracks and towers must be avoided as much as possible, and avalanche area must be avoided; choice of camp should avoid air inlet, and try some flat land. In addition, it requires the team member to have full equipment and tough skills.

\section{c) Feasibility}

The distance between camps should not be too far. According to the physical energy of the team members, they can keep walking for 6 to 8 hours, so that it can guarantee the physical recovery and transportation of materials, and meanwhile guarantee the safety, rescue and supply of later team members. In addition, there must be safe and flat area for good observation of the summit and facilitate camp setting.

\section{d) Emergency}

If emergency (such as the altitude reaction and hypothermia, etc.) arises, the climbing route shall guarantee that the team members can rapidly and safely retreat to lower-altitude camps and meanwhile guarantee rapid upclimbing of supporting team members.

\section{2) Climbing route of Ruoni Mountain II}

\section{a) Route survey}

According to field observation, measurement and discussion of team members from both countries, an appropriate climbing route is chosen. During this mountaineering process, pioneering road repairing team members and the observing team members of the major camp cooperated closely. By repeatedly studying the 
position of the climbing routes through telescope, camera, interphone and other equipment, the finally chosen route cannot only successfully avoid the area prone to avalanche, but the climbing route is clear and relatively short for easy observation and climbing [3]. See Figure 1.

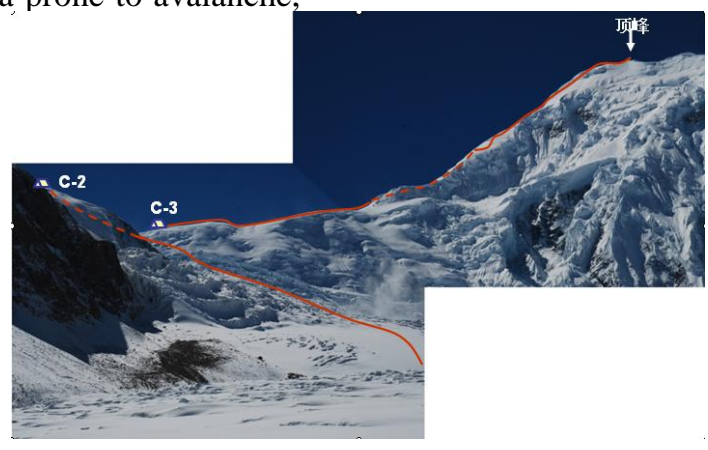

Figure 1. Climbing route of Ruoni Mountain II

Through GPS field measurement, see Table 2 for the recorded data.

TABLE II. PARAMETER ANALYSIS OF THE CLIMBING ROUTE OF RUONI MOUNTAIN II

\begin{tabular}{ccccc}
\hline & $\begin{array}{c}\text { Altitude } \\
(\mathbf{m})\end{array}$ & Longitude & Latitude & Road condition between camps \\
\hline$C 1$ & 4750 & $96^{\circ} 44^{\prime} 38^{\prime \prime}$ & $29^{\circ} 13^{\prime} 01^{\prime \prime}$ & $\begin{array}{c}\text { Kept Climbing up, there were many ice towers and cracks; fixed } \\
\text { rope was needed when 500m away from C2 }\end{array}$ \\
\hline$C 2$ & 5800 & $96^{\circ} 43^{\prime} 53^{\prime \prime}$ & $29^{\circ} 11^{\prime} 43^{\prime \prime}$ & $\begin{array}{c}\text { Roads were very rough, and fixed rope was needed for certain } \\
\text { road sections. }\end{array}$ \\
\hline C3 & 5900 & $96^{\circ} 42^{\prime} 43^{\prime \prime}$ & $29^{\circ} 11^{\prime} 27^{\prime \prime}$ & There was deep snow and great wind in the high altitude \\
\hline Reaching the summit & 6805 & $96^{\circ} 41^{\prime} 42^{\prime \prime}$ & $29^{\circ} 12^{\prime} 15^{\prime \prime}$ & \\
\hline
\end{tabular}

b) Choice of route

C1 to C2: C1 directly faced towards Ruoni Mountain II, and its safe distance from Ruoni Mountain II was only $3 \mathrm{~km}$. C2 was located in the saddle of Ruoni Mountain I and Ruoni Mountain II. For choice of routes, it needs to steer clear of glacier and avalanche area. Moreover, according to previous mountain climbing experiences of other mountains, for some places where there were no glacier or avalanche but deep snow, it is highly energy-consuming for climbers, so that these places should also be avoided. From $\mathrm{C} 1$ to $\mathrm{C} 2$, the team first passed a small $500 \mathrm{~m}$ long crack zone, and then passed a snow upslope of about $30^{\circ}$ and $300 \mathrm{~m}$ long. Then the team entered a $200 \mathrm{~m}$-wide ice tower, and then there was snow slope of $35^{\circ}$. There were exposed and concealed cracks on the slope. Following this, the team passed a large ice tower and snow and ice accumulation, and reached the saddle of the mountain after another slope of $300 \mathrm{~m}$ and $20^{\circ}$.

C2 to C3: C3 was in the ridge, with the height over $100 \mathrm{~m}$ compared to $\mathrm{C} 2$, and a distance of $2 \mathrm{~km}$. For choice of route, it needs beveling along the snow slope up the mountain ridge. In order to save energy, climbers needed large ice slope mountaineering was needed and shifted to snow board for deep-snow road sections. There were cracks in this road section. Moreover, snow board should be worn once the mountaineering got started. There was an ice wall with gradient of $80^{\circ}$ and height of $6 \mathrm{~m}$ in the middle which needed ice crampon for climbing. When approaching $\mathrm{C} 3$, there was a crack-intensive zone of about 200m, and some concealed cracks were difficult to be noticed.

C3 to the summit: for choice of route, climbers needed to walk along the ridge as much as possible. Under the premise of avoiding strong wind, the accumulated snow on the mountain ridge was hard and difficult for falling. It was also beneficial for team members to save energy. The route of $\mathrm{C} 3$ to the summit was a difficult road section of the entire summit, with average gradient of $45^{\circ}$ to $50^{\circ}$; there were hard snow between C3 to the altitude of $6300 \mathrm{~m}$, of which there were few cracks but highly risky of falling. When approaching $6,300 \mathrm{~m}$, there were about $100 \mathrm{~m}$ long steep road. Up from $6,300 \mathrm{~m}$, snow depth was over $30 \mathrm{~cm}$; while reaching $100 \mathrm{~m}$ away from the summit, the snow depth surpassed $60 \mathrm{~cm}$. Moreover, there was a snow wall of about $10 \mathrm{~m}$ high, which might be detoured. Following that and finally, the climbers reached the summit of Ruoni Mountain II [4].

c) Evaluation of this climbing route

Due to terrain restrictions of the mountain, the climbing route is extremely long, and it needs five to six camps to successfully reach the summit. It also increases the difficulty and times of food transportation, technical equipment and personal equipment, all of which is a terrible 
ordeal on the stamina and will of climbers. Particularly, the long route of $\mathrm{C} 1$ to $\mathrm{C} 2$ has a height difference of 1050 increases the climbing difficulty. Due to the particularity of summit, the height difference between $\mathrm{C} 3$ to the summit is nearly $1000 \mathrm{~m}$, which seriously tests the stamina, climbing technique and will of the team members. See Table 3 for evaluation of the climbing route.

TABLE III. EVALUATION ON THE CLIMBING ROUTE

\begin{tabular}{ll}
\hline \multicolumn{1}{c}{ Advantages } & \multicolumn{3}{c}{ Disadvantages } \\
\hline $\begin{array}{l}\text { The route is clear and facilitates } \\
\text { observation and contact }\end{array}$ & $\begin{array}{l}\text { Climbers have to pass through } \\
\text { multiple dangerous road } \\
\text { sections. }\end{array}$ \\
\hline $\begin{array}{l}\text { Camps are on the leeward side, and } \\
\text { contact between camps are clear } \\
\text { and convenient }\end{array}$ & $\begin{array}{l}\text { Choice of camp is highly } \\
\text { restrictive, } \\
\text { Camps are distant from each } \\
\text { other }\end{array}$ \\
\hline $\begin{array}{l}\text { Technical requirements for later } \\
\text { climbing are low and easy to pass }\end{array}$ & $\begin{array}{l}\text { Early road repairing is } \\
\text { dangerous due to many } \\
\text { concealed cracks. }\end{array}$ \\
\hline
\end{tabular}

See Table 4 for dangerous road sections that need special attention on this climbing route.

\section{TABLE IV. IMPORTANT NOTES ON THE CLIMBING ROUTE}

\begin{tabular}{|c|c|}
\hline Safety notes & Danger notes \\
\hline $\begin{array}{l}\text { There is an ice tower after } \\
\text { walking } 500 \mathrm{~m} \text { from } \mathrm{C} 1 \text {, which } \\
\text { needs careful observation to } \\
\text { determine a safe passage and } \\
\text { have it be marked with roadmap. }\end{array}$ & $\begin{array}{l}\text { Do not enter the ice tower blindly } \\
\text { to avoid loss of direction, slipping } \\
\text { and falling or concealed cracks. }\end{array}$ \\
\hline $\begin{array}{l}\text { There is a wind gap at altitude } \\
5,200 \mathrm{~m} \text { between } \mathrm{C} 1 \text { and } \mathrm{C} 2 \text {, } \\
\text { which needs fixed rope. }\end{array}$ & $\begin{array}{l}\text { Down jacket is needed to avoid loss } \\
\text { of temperature. }\end{array}$ \\
\hline $\begin{array}{l}\text { Snow board is needed for the } \\
1000 \mathrm{~m} \text { before } \mathrm{C} 2 \text { to } \mathrm{C} 3 \text { to save } \\
\text { energy. }\end{array}$ & $\begin{array}{l}\text { There is gravel slope while coming } \\
\text { out of C } 2 \text { campsite to avoid } \\
\text { slipping and falling by wearing } \\
\text { snow board. }\end{array}$ \\
\hline $\begin{array}{l}\text { When approaching the summit, } \\
\text { the snow is deep and soft, and } \\
\text { climbers should climb in roped } \\
\text { party. }\end{array}$ & $\begin{array}{l}\text { There is deep snow and large wind, } \\
\text { and climbers should watch out for } \\
\text { slipping and falling }\end{array}$ \\
\hline
\end{tabular}

\section{CONCLUSION AND SUGGESTIONS}

\section{A. Conclusion}

Climbing route of Ruoni Mountain II has altitude rise of $2,055 \mathrm{~m}$ from $\mathrm{C} 1$ to the summit, which crosses longitude of $2^{\prime} 56^{\prime \prime}$ and latitude of $0^{\prime} 46^{\prime \prime}$, with average gradient of $40^{\circ}$. There are ice towers on the route; for dangerous road sections such as exposed or concealed cracks, climbers should climb in roped party or use road ropes to prevent from falling into ice cracks or slipping and falling. Roadmap should be used to avoid loss of direction and bypassing dangerous road sections, and the impact of large wind and temperature loss should also be avoided.

\section{B. Suggestions}

- There are many unknown factors for climbing an unclimbed mountain, and climbers should be trained with roped partying or rescue techniques.

- Before entering the mountain, data collection, sorting and material preparation for unclimbed mountain should be fully prepared.

- The climbing route should be carefully determined under full consideration of route design principle, and the climbing route should be determined based on the actual field conditions.

- Due to global warming, the route may have certain changes after several years, and there may be appropriate adjustment according to the specific conditions of climbing.

\section{REFERENCES}

[1] SUN Fangmin, CHEN Lingxia, and SUN Xiuhua, "The history of science development”, Zhengzhou: Zhengzhou University Press, 2006. 25.

[2] DONG Fan, NIU Xiaohong, and LI Lun, "Mountaineering", Wuhan: China University of Geosciences Press, 2009. 2.

[3] GUO Chunxi, WANG Bin, CHENG Chuanlu, and PANG Shangyi, "Qomolangma height surveying in 2005", in Journal of Earth Sciences and Environment,vol. 3, 2009, p. 107.

[4] "The China outdoor sports industry web portal: review of climbing ruoni mountain II - joint climbing team of China University of Geosciences (Wuhan) - Kobe University of Japan", [EB/OL], http://www.8264.com. 